\title{
Liquidity Trap: the Brazilian version ${ }^{1}$
}

\author{
Fernando Ferrari Filho \\ Marcelo Milan ${ }^{3}$
}

\begin{abstract}
The goal of this paper is to provide an interpretation about the sky-high real interest rates in Brazil. We use Keynes' argument regarding liquidity trap to identify the forces trapping interest rates, but in Brazil they are trapped at very high levels instead of at the zero-lower bound discussed in Keynes's General Theory. Rentiers, in Brazil, influence the Brazilian Central Bank to obtain very liquid assets in the form of Financial Treasury Bills (LFTs) while keeping high interest earnings. In this case expansionary fiscal policies will have a limited impact on output, given the resulting high debt levels and debt service, but will imply significant income transfers to the rentiers. This means that aggregate demand and income will be less sensitive to fiscal stimuli, but the distribution of income will be biased toward the rentiers.
\end{abstract}

Keywords: Liquidity Trap; Interest Rates; Public Debt; Rentier; Brazilian Economy.

JEL Classification: E12; E43; E52; E58.

\footnotetext{
${ }^{1}$ The authors would like to thank two anonymous referees. They acknowledge all remaining errors as their responsibility.

${ }^{2}$ Visiting professor at the Graduate Program of Economics (Federal University of Rio Grande do Sul), visiting professor at the Williams School of Commerce, Economic, and Politics (Washington and Lee University/USA) and Researcher (level 1c) at CNPq. E-mail: ferrari@ufrgs.br.

${ }^{3}$ Associate Professor at the Department of Economics and International Relations and at the Graduate Program in International Strategic Studies (Federal University of Rio Grande do Sul). Email: Marcelo.milan@ufrgs.br.
} 


\section{Introduction}

Since the creation of the ORTN (Adjustable Obligation of the National Treasury ${ }^{1}$ ) in 1964, high real interest rates have been the main characteristic of the Brazilian monetary and financial markets. Considering, only the period from the adoption of the Inflation Targeting Regime (ITR), in 1999, until 2016 - by the way, this is the period when increasing the policy interest rate, that is, the Special System for Settlement and Custody of Government Bonds (Selic), was seen as the main tool for keeping inflation under control -, the average annual interest rate was $14,2 \%$, in nominal terms, and $6,9 \%$, in real terms. ${ }^{2}$

Economists from different theoretical approaches argue that the Brazilian interest rates are so high, mainly comparing with other emerging countries, due to one or more of the following reasons: history of hyperinflation in the past, low saving rates, subsidized credit to industry and agriculture, large government deficits and public debt, jurisdictional uncertainty and financial conventions. ${ }^{3}$ For us, however, the main reason why the interest rates are so high in Brazil is related to the pressure from the rentier segment (financial institutions, financialized industrialists, and wealthy households) to frame monetary and fiscal policies, including debt management, in a way to sustain very high interest earnings in a context where inflation is not very sensitive to monetary policy. In other words, the idea is that there is a convention, characterized by a coalition of interests between the financial market and the rentiers, about the payment of interest rates to roll over the public debt.

Considering our hypothesis about the high interest rates in Brazil, the objective of this article is to show that, contrary to the Keynes' view of a liquidity trap (Keynes, 2007), which refers to the phenomenon when an increased money supply fails to lower interest rates, because they are already close to the zero lower bond, the Brazilian Central Bank (BCB) implements a restrictive monetary policy to satisfy the rentier's expectations related to their financial gains, given the indexation of the government securities (Financial Treasury Bills or LFTs). In this case, real interest rates are trapped at relatively high levels instead of near-zero rates. That is why we call it "Brazilian version", since this two-pronged strategy, framing both monetary policy, to sustain high interests based on rentier's inflationary expectations, and fiscal policy to finance deficits with TIPS indexed to

${ }^{1}$ ORTN is a type of TIPS (Treasury Inflation-Protected Security).

2 Authors' calculations based on statistical information from Ipeadata (2018).

${ }^{3}$ See, for instance, Arida et al. (2005), Barbosa (2006), Holland (2006), Modenesi et al. (2013), Paula and Bruno (2017) and Seabra and Dequech (2013). 
the very interest rates which are indexed to the banking and capital market's inflationary expectations ${ }^{4}$ seems to be singular. In this article we attempt to understand the first thread of rentiers' influence, highlighting the monetary policy channel. A complementary study about the framing of debt management is underway.

In order to achieve the above goal, besides the Introduction, the article is divided into three more sections. The next one presents the Keynes arguments related to the monetary policy and liquidity trap, as well as it shows the interpretation of Keynes' liquidity trap made by the Neoclassical Synthesis (NS). The third section provides an explanation based on our main hypothesis, that is, the Brazilian liquidity trap based on the idea that rentiers frame monetary policy in a way to sustain very high interest earnings. Finally, section concludes the article.

\section{Monetary policy and liquidity trap: from Keynes to NS}

\subsection{The Keynesian view}

As we know, in The General Theory of Employment, Interest and Money (hereafter GT), Keynes argues that "[ $\mathrm{t}]$ he outstanding faults of the economic society [...] are its failure to provide for full employment and its arbitrary and inequitable distribution of wealth and incomes" (Keynes, 2007, p.372). To mitigate or solve these faults, Keynes proposes the use of an arsenal of economic policies, mainly fiscal, or the "socialization of investment", monetary, and social. Focusing our attention on monetary policy alone in this study, Keynes argues that, on the one hand, it should be managed "to maintain the level of investment at a high enough rate to ensure the optimum level of employment" (Keynes, 1982, p.137), and, on the other hand, should be operated to cause "the euthanasia of the rentier." (Keynes, 2007, p.376).

\footnotetext{
${ }^{4}$ The inflationary expectations are based on Focus Report produced, weekly, by the BCB. This Report analyses the projections of some private banks and capital markets, including investment agencies and consultant companies, related to inflation rate, interest rate, exchange rate and GDP growth, among others, for the Brazilian economy. In general, it is possible to observe that there is a positive relationship between the 12 months ahead expected of inflation by the Focus and the increase of Selic, determined by the monthly meeting of the Monetary Policy Committee (COPOM); that is, the interest rate is preceded by the inflation expectations. Thus, the financial market is able to anticipate the changes in the Selic rate, or to influence it. For additional details related to Focus Report, see: Focus - Relatório de Mercado (BCB, 2018a). Moreover, this relation was shown by Zabot et al. (2013), from a mainstream perspective, and by Mendonça (2018), from a heterodox view.
} 
Why monetary policy is an important instrument to achieve this strategy? Because, in a Keynesian perspective, monetary policy has five goals: (i) As Keynes (1982) argues, one of these is price stability. Inflation affects expectations as long as it devalues wealth, shortens the long haul, and unleashes liquidity preference, likely to lead the economy to an insufficient effective demand; ${ }^{5}$ (ii) Another goal is "to bring to the forefront a form of monetary and financial policy, which is focused on financial stability ${ }^{6 \prime}$ (Arestis and Sawyer, 2013, p.163). In this sense, financial stability should turn the financial system into an instrument to financing productive investments, households' spending plans, and foreign trade, instead of providing "short-term gains for shareholders and huge profits for themselves" (Arestis, 2015, p.24); (iii) Since it is by means of expectations and liquidity preference that monetary policy transmits its effects, a good state of expectations is required for the success of central bank's measures. This makes the third goal of monetary policy to be the maintenance of stable expectations. If misguided prospects about the future predominate, they result in volatile speculative and precautionary money demand, turning monetary policy ineffective; (iv) The fourth goal is the supervision and control of the economic system's liquidity. This means that monetary policy needs to avoid a generalized shortage of liquidity, as well as it should prohibit banks from creating money and liquid assets in excess. Moreover, when controlling liquidity, central banks also act as lenders of last resort, preventing bankruptcy of financial institutions and its financial contagion risks; and (v) The last goal of monetary policy is to stabilize the "value [of money] in terms of an international standard" (Keynes, 1982, p.128), that is, the exchange rate stability. Exchange rate movements have a vast influence not only on expectations, but also on the firm's financial and operational stances.

In order to reach these goals, according to Keynes (1971), the central bank has to manage the monetary policy wisely, because the interest rate has transmission channels - such as portfolios, credit agreements, value of wealth, expectations and exchange rate ${ }^{7}$ - that affect effective demand and, consequently, economic growth and employment, and therefore also income and wealth distribution. More specifically, considering that " $[\mathrm{t}]$ he rate of interest is not the 'price' which brings into equilibrium the demand for resources to invest with the

\footnotetext{
${ }^{5}$ It is important to mention that, according to Davidson (1994), the main causes of inflation, in a Post-Keynesian perspective, are: (1) Profit or monopolist price-making; (2) Wage increases; (3) Decreasing returns to scale; (4) External factors; (5) Supply-shocks; (6) Tax elevations; and (7) Demand-shocks.

${ }^{6}$ Financial stability is understood as the absence of asset price bubbles, illiquidity, and insolvency.

${ }^{7}$ As argued in Arestis et al. (2016).
} 
readiness to abstain from present consumption. It is the 'price' which equilibrates the desire to hold wealth in the form of cash with the available quantity of cash" (Keynes, 2007, p.167), the central bank has to operate the monetary policy effectively to expand effective demand and affect the liquidity preference or 'propensity to hoard' of economic agents. ${ }^{8}$

Why economic agents prefer liquidity trap or display 'propensity to hoard'? In the GT, Keynes argues that, in a context of fundamental/radical uncertainty, in which is not possible to predict the future, economic agents prefer to hold on money and, consequently, their decisions on expenditures, consumption and, especially, investment, are postponed. Thus, cash is an alternative and useful form of wealth in times of uncertainty.

Given the above-mentioned transmission channels of monetary policy, a question arises: what are the main transmission channels and how do they affect directly the effective demand and the level of employment and the income and wealth distribution? As argued in Arestis et al. (2016), the main transmission channels identified in the literature include portfolio changes, credit agreements, changes in the value of wealth, and expectations. They are affected by interest rates, and by their turn have effects on the economic system:

i. The portfolio channel is affected by the interest rate due to its impact on the opportunity cost of investment. According to Keynes' (2007, chapter 17) asset pricing theory, this channel acts by virtue of how agents and banks allocate their portfolios, based on the assets' expected return, cost of carrying it all, and liquidity. Thereby, as soon as the central bank interest rate starts moving, the yield-curve shifts as a result of the general reaction

\footnotetext{
${ }^{8}$ According to Keynes, the liquidity trap or 'propensity to hoard' can be extreme in a context of high uncertainty. As Keynes (2007, p.201) argues, "the relation between $M_{2}$ [the amount of money to satisfy the speculative-motive] and $r$ [interest rate] [shows] that uncertainty as to future course of the rate of interest is the sole intelligible explanation of the type of liquidity-preference $L_{2}$ which leads to the holding of cash M." For Davidson (1994, p.117), this situation, in which "the demand curve for speculative money balances becomes infinitely elastic (horizontal) at some low but positive interest rate" was labeled incorrectly as the liquidity trap. In other words, the liquidity trap would be the situation in which the interest rate is close to zero and changes in the money supply are not able to affect the liquidity trap, making monetary policy ineffective. That is one of the reasons why the "Brazilian version" of the phenomenon is so interesting. In Brazil there is no uncertainty about interest rates, since they are regularly set based on inflationary expectations of financial market participants. This means that these participants do not need to hoard cash. They instead stockpile highly liquid bonds, FLTs, whose yield depends on the short-term interest rates kept at high levels by the Central Bank, and which are by design protected against inflation losses. This means that another source of uncertainty, the changes in the price levels, is hedged by the way the monetary and fiscal policies are framed.
} 
to the changed circumstances, felt throughout the financial system. As a consequence of how the portfolio channel impacts investment spending, the use of interest rates as the main monetary policy tool should be parsimonious; it represents an opportunity cost to investment, so that it competes with the alternative that affects employment and wealth creation.

ii. The interest rate also has impacts on the credit channel, but actually affecting also the capital market. In the capital market, the interest rate translates itself into effective costs of investing. As Keynes (1971) argued, if agents want to buy debt issued by firms for funding their investments, but they do not have sufficient reserves to do so, 'borrowing to lend' is the option. So, interest rate shifts modify the spread between the interest rate charged on the borrowing and the yields given by 'lending' the borrowed money in the form of securities, changing the volume of funds supplied in the capital market. The other credit channel impact occurs in the credit market properly: (a) Households borrow to spend and, as Keynes (2007, p.196) affirmed, this demand for money "will partly depend on the cheapness and the reliability of methods of obtaining cash, when it is required, by some form of temporary borrowing." Then, higher credit costs reduce this sort of borrowing, pressing effective demand down; and (b) Likewise, firms borrow funds to finance working capital, and the augmented interest rate modifies their cash flows and, as a result, profits, which might culminate in a price adjustment on the part of firms.

iii. The wealth channel, as Keynes $(2007$, p.94) recognized, is "perhaps the most important influence, operating through changes in the interest rate, on the readiness to spend out of a given income." The transmission relies on the impact that interest rate shifts have on the market price of financial assets and depends on the degree that households use this changed price to finance their consumption. The more consumption is financed by this kind of income variation, the larger is the effect of this transmission channel.

iv. The interest rate is fundamental to affect the expectations of the economic agents. In short, an 'appropriate' interest rate is able to stimulate the economic agents' animal spirits and mitigate their "love of money as a possession" (Keynes, 1972, p.329). In other words, it can become a 'convention' and influence the state of confidence of economic agents. About it, Keynes (2007, p.197-198) pointed out that

[i]t is, however, important to distinguish between the changes in the rate of interest which are due to changes in the supply of money available to satisfy the 
speculative-motive, without there having been any change in the liquidity function, and those which are primarily due to changes in expectation affecting the liquidity function itself; Open-market Operations may, indeed, influence the rate of interest through both channels; since they may not only change the volume of money, but may also give rise to changed expectations concerning the future policy of the central bank or of the government.

If expectations are as stable as it is required for conducting effective monetary policy, the difference of judgments that agents have about the future interest rates would set their liquidity preference at different levels, motivating them, for example, to negotiate debt or credit contracts. While agents negotiate liabilities, there is room for monetary policy to sell and buy the government securities with which it engages in open market operations. Nevertheless, a diversity of individual expectations only happens if the central bank is able to maintain a stable state of expectations in the economy as a whole. ${ }^{9}$ Otherwise, if the central bank fails at this attempt, conventions in the financial system would be disorganized, driving expectations towards a strong liquidity preference. As such, open market operations would have no way to succeed, and monetary policy would not achieve its goals.

Summing up, in the Keynesian perspective monetary policy is a powerful instrument to stimulate investment and, as a result, expand economic growth and the level of employment. However, if economic agents decide to change their portfolio strategies, culminating in an increased liquidity trap and unstable speculative demand for money, the central banks are not able to implement monetary policy.

\subsection{The NS interpretation of the Keynesian monetary approach}

The view expressed above is not universally accepted. Keynes' views were adapted and transformed to make it amenable to the existing neoclassical paradigm. This is due to some ambiguous passages in his magnum opus. On chapter 14 of the GT, Keynes, analyzing the classical theory of the rate of interest, states that

[i]f the classical school merely inferred [...] that, given the demand curve for capital and the influence of changes in the rate of interest on the readiness to save out of given incomes, the level of income and the rate of interest must be uniquely correlated, there would be nothing to quarrel with. Moreover, this proposition would lead naturally to another proposition which embodies an important truth; namely, that, if the rate of interest is given as well as the demand curve for capital

\footnotetext{
9 That is why, in addition to being a transmission channel, expectations are a goal and a condition for a successful or effective monetary policy. Bearing all this in mind, we may argue that the expectations channel is a kind of 'channel before other channels' since it is the diversity of opinions about the future interest rates that would make it possible for monetary policy to alter interest rates so that the other channels can indeed transmit their effects on effective demand.
} 
and the influence of the rate of interest on the readiness to save out of given levels of income, the level of income must be the factor which brings the amount saved to equality with the amount invested. (Keynes, 2007, p.178-179, italics added)

Perhaps the above quotation inspired Hicks (1937) to elaborate his IS-LM model and interpret the Keynesian disequilibrium as summarized by the existence of a liquidity trap. In his seminal article, Hicks formalizes three models - the "classical" model, "Keynes' special" model, and the "Keynesian" model - to show that, all of them, have behavioral equations that define the same IS-LM model: the LM curve represents the equilibrium in the money market, while the IS curve defines the equilibrium in the output market. ${ }^{10}$

In Hicks (1937) analysis, "Keynes' special" model differs from the "Classical" model in two points: the savings function and the demand for money function. Thus, Hicks emphasizes that one of the main differences between the referred models is associated with the demand for money: in the "Keynes' special" model the demand for money is explained by the liquidity trap function, while in the "Classical" model it is explained by the Cambridge version of the Quantity Theory of Money (QTM). However, Hicks claims that this difference is irrelevant, because, when comparing "Keynes' special" model with the "Keynesian" model, the introduction of the rate of interest in the Keynes' demand for money is not contradictory to the OTM. As a result, according to him, the demand for money, as showed in the GT, "is something appreciably more orthodox." (Hicks, 1937, p.152) This is associated with what Hicks understands to be Keynes' return to the orthodox monetary theory. In Hicks' own words, "[w]ith this revision, Mr. Keynes takes a big step back to Marshallian orthodoxy, and his theory becomes hard to distinguish from the revised and qualified Marshallian theories, which, as we have seen, are not new." (Hicks, 1937, p.53)

Why, according to Hicks, the Keynesian monetary theory became similar to the QTM, and therefore was not new at all? One reason is that, when the demand for speculative money is infinitely elastic with respect to the rate of interest, that is, in a context of liquidity trap, the demand for money in Keynesian and classical models would depend only on the income level. Consequently, Hicks argues that Keynesian involuntary unemployment persists due to the fact that monetary policy cannot lower the interest rate sufficiently to restore the economy to its full

\footnotetext{
${ }^{10}$ As it is well known, the IS-LM model, or Hicks (1937) and Hansen (1953) model, shows the combination of interest rate and output that equilibrates, simultaneously, investment and saving (IS curve) or the goods market, and liquidity trap and money supply (LM curve) or the financial assets and money market.
} 
employment income level. Therefore, he concludes that "the General Theory of employment is the Economics of Depression." (Hicks, 1937, p.155)

Given that, the NS or the hydraulic Keynesians "made the liquidity trap the hallmark of their [...] Keynesian theory when they proclaimed that fiscal policy was necessary to pull an economy out of a recession" (Davidson, 1994, p.117), and, as a result of that, the "liquidity trap [...] dominates in the immediate aftermath of a great depression or a financial crisis." (Minsky, 2008, p.36). Indeed, going in the direction of Minsky's argument, at the end of 2008 and beginning of 2009, when interest rates around the world fell, approximately, to zero, several economists brought back the traditional Hicks-Hansen, now Hick-Hansen-Krugman story about the liquidity trap. ${ }^{11}$

We can therefore conclude that: (i) low interest rates do not define a liquidity trap and "Keynes had never claimed there was a liquidity trap" (Davidson, 1994, p.117); (ii) for Keynes and Post-Keynesians a liquidity trap is a situation in which people hoard cash because asset prices strongly fell, due to deflation, and their expectations are uncertain. Given that, the conventional monetary policy cannot affect the speculative-motive for money; and (iii) Keynes' theory cannot be interpreted as the situation in which unemployment is a temporary phenomenon due to the existence of the liquidity trap. In this circumstance, the Hicks-Hansen model shows, wrongly, that Keynes solution for unemployment is focused only on fiscal policy.

\section{Monetary policy ineffectiveness and rentier's interests in Brazil}

There is a liquidity trap, in the Post-Keynesian meaning of the term, in Brazil, even though it might be a different type of trap? In order to answer this question, it is necessary to understand how monetary policy works (or does not work) in Brazil.

\subsection{Brief considerations about the ITR in Brazil}

Monetary authorities have adopted the ITR in Brazil since 1999, along with a target for primary fiscal budget surpluses as share of GDP, and a de jure but not de facto floating exchange rate regime (the so-called tripod). Focusing our attention

\footnotetext{
${ }^{11}$ Krugman et al. (1998) developed an analysis of the Japanese economy based on Hicks's liquidity trap.
} 
on monetary policy alone, but keeping in mind that the fiscal policy, mainly the debt management part, is crucial for understanding the rentiers' strategy in Brazil of trapping interest rates at high levels, the $\mathrm{BCB}$ seems to have been broadly following the theoretical framework that underpins the ITR. According to Arestis et al. (2011), the main theoretical features of the BCB macroeconomic model, closely based on the New Consensus Macroeconomics (NCM) view, can be summarized as follows:

i. Price stability is the monetary policy's primary long-term objective. In addition, the price stability goal may be accompanied by output stabilization so long as price stability is not at risk;

ii. Fiscal policy is no longer viewed as a powerful macroeconomic instrument for stabilizing the economy. Hence, the economic authorities should adopt a fiscal target in terms of a primary budget surplus. This means that the Treasury has also been influenced by the orthodox view that it is necessary to sustain high primary budget surpluses in order to stabilize the debt-toGDP ratio;

iii. The level of economic activity fluctuates around a supply-side long-run equilibrium. This means that the level of effective demand does not play an independent role on the long-run level of economic activity;

iv. Finally, considering that the Brazilian economy is open, with a history of external imbalances and payment crises, the exchange rate is of crucial importance, because it transmits external shocks to the interest and inflation rates. Given that, in the $\mathrm{BCB}$ macroeconomic framework, it is assumed that the ITR may lead to a more stable currency, since it signals a clear commitment to price stability under a de jure floating exchange rate system.

The policy interest rate target is set by COPOM for the Selic, the market interest rate for overnight interbank loans, collateralized by treasury securities, part of which are indexed to these very interest rates. The interest rate target is fixed for the period between the COPOM regular meetings and taking into account a survey of inflationary expectations among financial institutions. Thus, based on the economic outlook scenario expected by the financial market, the BCB elaborates the minutes of the meetings of the COPOM that, in general, shows that inflation expectations collected by the Focus Report influence the changes of Selic. This entire arrangement is what explains, in our view, the interest rates trapped in high levels in Brazil, and a preference for liquid long-term government treasuries indexed to these short-term interest rates. Liquidity preference here is not about hoarding 
cash due to uncertainty about higher future interest rates causing capital assets to lose value, but about holding TIPS whose yields depends on the inflationary expectations of the holders themselves. And those expectations back the formation of the policy interest rate that compensate bondholders.

After the adoption of the ITR, however, inflation remained at relatively high levels compared to the world economy average, which was $4,1 \%$ for the same period. Table 1 shows that, over this period, the upper limits of tolerance were missed for the years 2001, 2002, 2003 and 2015 by a substantial margin, especially in 2002 and 2015, while in 2004 the inflation target was only met after it was raised by mid-2003. Also, the inflation rates were above the point targets in nine years (1999, 2004-2005, 2008, and 2010-2015).

Table 1. Inflation Targets and Inflation Rates (IPCA), Selic and Growth Rates, \% (1999 to 2016)

\begin{tabular}{|c|c|c|c|c|c|c|}
\hline Year & $\begin{array}{c}\text { Point } \\
\text { Targets }\end{array}$ & $\begin{array}{c}\text { Tolerance } \\
\text { Intervals }\end{array}$ & $\begin{array}{c}\text { Effective } \\
\text { Headline } \\
\text { Inflation } \\
\text { Rates } \\
\text { (IPCA) }\end{array}$ & $\begin{array}{c}\text { Annual } \\
\text { Nominal } \\
\text { Interest } \\
\text { Rate } \\
\text { (Selic) }\end{array}$ & $\begin{array}{c}\text { Annual } \\
\text { Real } \\
\text { Interest } \\
\text { Rate }\end{array}$ & $\begin{array}{c}\text { Annual } \\
\text { Real } \\
\text { Output } \\
\text { Growth } \\
\text { Rate }\end{array}$ \\
\hline 1999 & 8 & 6 to 10 & 8,94 & 19,0 & 9,2 & 0,3 \\
\hline 2000 & 6 & 4 to 8 & 5,97 & 15,75 & 9,2 & 4,3 \\
\hline 2001 & 4 & 2 to 6 & 7,67 & 19,0 & 8,5 & 1,3 \\
\hline 2002 & 3,5 & 1,5 to 6,5 & 12,53 & 25,0 & 11,1 & 3,1 \\
\hline 2003 & 4 & 1,5 to 6,5 & 9,3 & 16,5 & 6,6 & 1,3 \\
\hline 2004 & 5,5 & 3,5 to 8 & 7,6 & 17,75 & 9,4 & 5,7 \\
\hline 2005 & 4,5 & 2,5 to 7,5 & 5,69 & 18,0 & 11,6 & 3,1 \\
\hline 2006 & 4,5 & 2,5 to 7,5 & 3,14 & 13,25 & 9,8 & 4,0 \\
\hline 2007 & 4,5 & 2,5 to 6,5 & 4,46 & 11,25 & 6,5 & 6,0 \\
\hline 2008 & 4,5 & 2,5 to 6,5 & 5,9 & 13,75 & 7,4 & 5,0 \\
\hline 2009 & 4,5 & 2,5 to 6,5 & 4,31 & 8,75 & 4,3 & $-0,2$ \\
\hline 2010 & 4,5 & 2,5 to 6,5 & 5,91 & 10,75 & 4,6 & 7,6 \\
\hline 2011 & 4,5 & 2,5 to 6,5 & 6,5 & 11,0 & 4,2 & 3,9 \\
\hline 2012 & 4,5 & 2,5 to 6,5 & 5,84 & 7,25 & 1,3 & 1,8 \\
\hline 2013 & 4,5 & 2,5 to 6,5 & 5,91 & 10,0 & 3,9 & 2,7 \\
\hline 2014 & 4,5 & 2,5 to 6,5 & 6,41 & 11,75 & 5,0 & 0,1 \\
\hline 2015 & 4,5 & 2,5 to 6,5 & 10,67 & 14,25 & 3,2 & $-3,8$ \\
\hline 2016 & 4,5 & 2,5 to 6,5 & 6,29 & 13,75 & 7,0 & $-3,6$ \\
\hline
\end{tabular}

Source: Author's elaboration based on BCB (2018b). Note: (1) End of period; (2) Annual Interest Rate (Selic)/IPCA; and (3) The original inflation target for 2004 was 3,75\% (with a tolerance interval of $2,5 \%$ ). Subsequently, the $\mathrm{BCB}$ changed the inflation target to $5,5 \%$ and kept the $\pm 2,5 \%$ of tolerance interval 
It is important to emphasize that the monetary policy has been less effective in achieving inflationary stability (as Table 1 shows) due to two specific reasons: (i) the existence of failures in the transmission mechanisms of monetary policy; and (ii) the fact that, contrary to the ITR that assumes that inflation is mainly a phenomenon of excess demand, the Brazilian inflation is not, necessarily, related to the demand-pull process. ${ }^{12}$ Thus, considering that inflation is not mainly caused by demand factors, interest rates will have a limited effect on price dynamics.

Despite the modest results in terms of an effective reduction in inflation, monetary policy has been characteristically tight, placing Brazil in the top positions in the ranking of countries with the highest interest rates in the world, and causing serious constraint on economic growth, through the price of credit (loan rates) and entrepreneurs' poor expectations, as discussed in the previous section.

In this sense, in the period 1999-2016, GDP has followed a stop-and-go pattern, and its average growth rate hovered around $2,7 \%$ per year, significantly below the average growth rate of other emerging countries that have adopted an ITR (Arestis et al. 2011) and also of other countries not adopting it. However, by analyzing the relationship between the interest rate and inflation, we can realize that this relationship is, at most, weak.

In addition to the depressive effects on economic activity, the ITR has led to several serious imbalances, both in the domestic realm and in the external sector, as we discuss in the following section. More important, since the impacts of high interest rates on output may be significant, but the impacts on inflation are less pronounced, this creates a substantial change in the distribution of income.

However, for holders of government securities, since interest rates are indexed to inflation by the very design of the ITR, and a significant fraction of securities held are indexed to interest rates (LFTs), it provides a protection against inflation at the same time that it provides a stable and sizable source of earnings in the form of interest transfers from taxpayers to bondholders (Weisbrot, Johnston, Carrillo and Mello, 2017). Those transfers contributed to sustain nominal deficits, which are financed by new rounds of issuance of LFTs, which monetary policy insures against inflation by design in the ITR. So, high interest rates will not affect

\footnotetext{
${ }^{12}$ With respect to inflation being normally misdiagnosed in Brazil, some economists use to argue that there are other determinants of inflation, such as: the decision-making process of the leading price setters, exchange rate shocks, cost-push and distributive conflict. See, for instance, Arestis et al. (2011), Barbosa-Filho (2008), Modenesi and Araújo (2013) and Summa and Serrano (2018).
} 
inflation, but this is not relevant for rentiers, since they are protected against inflation by very high real interest earnings.

\subsection{ITR, interest rates, and rentiers behavior}

What are other possible explanations for the real interest rates in Brazil being trapped in high levels, besides the rentiers' two-pronged strategy? Dutt (1990) argues, from a theoretical perspective, that higher nominal interest rates in less developed countries (LDC) will reduce inflation - by hiking real interest rates concomitantly - only when capacity utilization is full. However, a different question concerns the level of interest rates necessary to bring inflation down under full capacity. Why would Brazil be required to have nominal interest rates well above most of the other countries in the sample in order to be able to achieve lower and more stable inflation rates? Again, according to the Dutt's idea (1990), Brazil must have an enormously large amount of idle capacity, since high interest rates are abnormally high. For the same reason, since average growth rates have been modest, then some idle capacity is likely to be taking place in Brazil, but not to the point of compensating for the sky-high interest rates. Therefore, there are high interest rates, relatively high inflation rates, and some unused capacity due to other factors that do not fit this interpretation.

Considering the Keynes' (1982) idea that, in a context of uncertainty about the future, one of the objectives of the monetary policy is to "stabilize" the economic agent's expectations, the interest rate becomes the main tool of monetary policy and acts on economic agents' liquidity-preference, which, on the one hand, depends on the their expectations and, on the other, explains the reason for speculative demand for money and so defines the market interest rate. Thus, the liquidity preference of bond holders requires high interest rates to pay a liquidity premium when the future is uncertain. This means that interest rate depends on the expectations of the financial markets, despite the fact that the monetary authorities controls the monetary policy. This is exactly our argument related to the "Brazilian version" of the liquidity trap. Going in this direction, Erber (2008, p.623-624) argues that the tight Brazilian monetary policy is the result of

a coalition of interests [that] was formed, structured by the public debt and the high interests earned on such debt. This coalition operates under a tacit agreement that the Brazilian State has to pay high interests and so must do other debtors. In other words, there is a convention firmly grounded on powerful interests, historically consolidated, about the payment of interest rates.

A more plausible explanation, in our view, is the two-pronged rentier strategy of framing monetary and fiscal (debt management) policies. This interpretation is not new and has been espoused, with some specific differences, 
by other authors. According to Bresser-Pereira and Silva (2008), the interest rate is very high in Brazil due to an interest/exchange rate trap. Arestis et al. (2011) claim that " $[t]$ he Selic rate is high because, since the end of the 1980s, the BCB has been 'captured' by rentiers who profit from high interest rates, by the financial sector which makes a living out of commissions/bonuses coming from rentiers" (2011, p.185). ${ }^{13}$ Thus, it is important to emphasize that the ITR is not necessarily the only culprit for the high interest rates in Brazil, since the phenomenon is at least almost four decades old according to them. The ITR could be seen as the newest achievement in terms of fostering the rentiers' interests (no pun intended), which in our view also includes the financial sector, to maintain their high interest earnings. By the same token, Vernengo (2005), analyzing the very first years of the ITR in Brazil, argues that the distributive conflict is important for the inflationary dynamics, not demand, and that indeed the monetary policy regime favors the financial sector interests within the rentier segment. Oreiro et al. (2012) argues that the Brazilian interest rate is so high because the bank spreads are so high.

Given that, some questions arise: How rentiers have been able to shape monetary and fiscal policies in Brazil in a way unseen in other countries and for such a long time? Why are they extraordinarily powerful in setting such successful interest-income transfer program? Samuels (2001) shows that, for example, banks, that are only a part of the financial system, have been among the most important contributors to finance political campaigns in Brazil. Nevertheless, under supposedly operationally autonomous central banks, this link between financial interests, politics, and monetary policy would be more opaque. We reject this type of explanation, since there is no need to keep bribing politicians if the rentiers have control over central banks and politicians no longer have such power (which is questionable in Brazil). It may be argued that rentiers' interests have been shaping the conduct of monetary policy since the military-corporate dictatorship from the 1960 s to the 1980s. And bankers also bribe politicians in other countries that have lower interest rates than Brazil. And there is still the fiscal policy part of the strategy. So, the explanation seems to be elsewhere.

\footnotetext{
${ }^{13}$ Smithin (1996, p.5) equally claims that "[t]he result [of negative real rates of interest] was ultimately a political revolution around the years 1979 to 1982, the most important feature of which was the 'capture' of central banks by rentier interests, and their conversion thereafter to exclusively 'hard money', high interest, and anti-inflation policies. This was the 'Revenge of the Rentiers' [...]". This means that the overall setting is pretty much the same in most of the Western World, but the way that rentiers control and influence monetary (and fiscal) policy differs among countries, as it is argued below. Their grip on the $\mathrm{BCB}$ and the Brazilian Treasury seems to be unique.
} 
The relationship between autonomous central banks, monetary policy, and fiscal policy, mainly government debt management, is better understood by the financialization literature. Bruno et al. (2011) show that the public debt, and the corresponding interest payments, is a major source of financialized capital accumulation in Brazil. It is possible to argue, based on this reasoning, that nonfinancial firms are also earning interest payments and are not opposed to high interest rates, being part of the rentier segment (which could explain the difficult of certain channels of monetary policy to work properly in Brazil). But are they able to set the monetary policy agenda as firmly as the financial institutions? We do not think so. Yet, the financialization literature is important to understand the fiscal policy part of the strategy, not discussed here for lack of space. But this literature does not discuss the channels between monetary and fiscal policies via specific types of securities, like the LFTs, which in our opinion is critical for understanding the "Brazilian version" of the liquidity trap.

Therefore, in our view, the influence of rentiers over monetary policy in Brazil, a very likely explanation for the stubbornly trapped high interest rates, has more to do with an institutional setting in which central banks are structurally constrained to keep nominal and real interest rates high, but in Brazil this framework has favored the rentier class on an unseen scale, with the result that monetary policy is not very effective in reducing and stabilizing inflation rates to the international average levels, but very effective in transferring income from taxpayers to rentiers. And our argument is that this institutional setting has to do with the inflationary expectations and the design of the ITR in Brazil. The BCB sets the short-term interest rate based on a survey of expected inflation mostly by financial institutions. Many issues seem to affect those expectations. For instance, despite the fact that the central government has never defaulted on its domestic debt, financial institutions, which hold a very large chunk of the government bonds indexed to short-term interest rates, seems to assume that the risk of default is permanently high, and therefore the interest rates must be kept at high levels in order to finance government deficits, which are to a large extent explained by past commitments to bondholders with transfers in the form of heavy interest payments (Weisbrot et al., 2017). This is an example of expectational trap.

The rentiers also seem to assume that monetary policy has not been credible, and expected inflation is rigid on the upper levels, even when actual inflation slightly falls. The solution is therefore to jack interest rates up even more. Inflation does not fall fast enough? Jack up one more time. If interest rates do not drop, therefore, it is because inflationary expectations are rigid due to the lack of 
genuine commitment with lower inflation rates. That is, a possible interpretation of rentiers power over monetary policy is that inflation rates do not fall in Brazil because expected inflation by financial firms, whose services have a small participation in the headline CPI, are rigid, and they are rigid because interest rates are kept unduly low, even though they are among the highest ones in the world. Interest rates in this case, according to rentiers in general and financial firms in particular, would only reflect the lack of credibility of monetary policy, and they are the only ones capable of defining what is credible and what is not. Credibility is hence defined as what financial firms think it is, even when it is explicit that credible policies seem to be only the ones that favor financial interests. If financial firms do not accept a policy, therefore, it is not credible by (their) definition (Grabel, 2003).

Thus, a consequence of rentiers' possible worldview, and that it is not espoused by this paper as argued before, is that expected inflation fully determines actual inflation rates, and the former do not fall because real interest rates are not high enough. But since interest rates also measure the rate at which capitalized monetary and financial wealth grows, it is our argument that rigid expected inflation rates have a major consequence in the form of transfer of funds, via indexed government securities, from the taxpayers to the rentiers whose expectations anchor the policy decisions by the BCB. So, it is highly convenient to have expectations disconnected from actual rates of inflation. It would certainly be outrageous for orthodox economists, mainly the ones working for the rentiers, if a rule of wage-setting was established such that nominal wages were automatically adjusted based on the workers and trade unions own inflationary expectations, surveyed by their own BCB-like institutions. But that is exactly what rentiers have accomplished themselves in Brazil. Thus, the expectations of rentiers seem to have transformed the ITR into an expectational trap, a powerful mechanism to sustain high interest rates (and earnings) in Brazil even though it has not had significant impacts on actual inflation rates, since they are not sensitive to credit-financed demand. As a consequence, indexed interest rates set according to bondholders' expectations of inflation pays off via interest-rate-indexed government bonds.

Exhibit 1 proposes a tentative theoretical classification for the different combinations of nominal interest and actual inflation rates as a way to interpret different types of monetary policy. The abnormal power of rentiers in Brazil in setting the monetary policy in specific type of liquidity trap makes it hard to classify the country using only this scheme, however, since interest rates in Brazil are very trapped at high levels, but the inflation rates are not low for international 
standards (although they are not higher than the ones prevailing in many developing countries). A possible answer lies in the fact that rentiers' maintain part of their wealth in the form of TIPS, and so are hedged against inflation. In this case the level of interest rates determines their level of interest earnings. The trap-like situation is further supported by a recent episode in Brazil, when public banks were enticed to boost competition and reduce market interest rates, along with policy rates reductions by the $\mathrm{BCB}$. It led to all types of financial "revolts" in the Brazilian press, including the financialized industrialists. This episode deserves a deeper treatment that is beyond the scope of this paper, since it raises the question of why and how the attempt at monetary policy change failed, and the potential role that rentiers' interests played in it besides the public opinion channel, since the BCB operates a policy framed by their interests (so, perhaps it cannot be easily twisted as thought by the political leaders).

Exhibit 1. A typology of monetary policy regimes ( $\mathrm{L}=\mathrm{Low}, \mathrm{H}=\mathrm{high}$ )

\begin{tabular}{|c|c|c|}
\hline Typology & Low inflation rate & High inflation rate \\
\hline High interest rate & $\begin{array}{c}\text { Rentiers' party/lneffective } \\
\text { monetary poly }\end{array}$ & $\begin{array}{c}\text { Rentiers' potentially } \\
\text { subdued/“Effective" } \\
\text { monetary policy }\end{array}$ \\
\hline Low interest rate & $\begin{array}{c}\text { Rentiers potentially } \\
\text { subdued/“Effective" } \\
\text { monetary policy }\end{array}$ & $\begin{array}{c}\text { Rentiers' hell/ Ineffective } \\
\text { monetary policy }\end{array}$ \\
\hline
\end{tabular}

Source: Author's own elaboration.

Yet, the Brazilian anomaly of an expectational trap that traps interest rates at high levels and still provides liquid assets to rentiers seems more close to a case of rentiers' party, with excessive real interest rates based not on low inflation, since the level of inflation does not affect most of their earnings anyway, but instead on exorbitant nominal interest rates, whereas other countries seem to have managed to subdue rentiers' interests, for some reasons that must be addressed by additional research, mainly regarding fiscal policies, with nominal interest rates closer to the inflation rates and therefore closer to Smithin's Rule of zero real interest rate (Smithin, 1996). Russia, on the other hand, would be an example of rentiers' hell, with, until recently, relatively low nominal interest rates and very high inflation rates.

Therefore, it is hard to defend ITR in Brazil as effective monetary policy under the guidance discussed in section 2. Considering the international standpoint, real interest rates have been excessive on several grounds, despite a fall during the center-left government, but not enough to bring it down to the 
international average. This requires a specific definition of this phenomenon. Conservative scholars and economists, rentiers, and international financial institutions, when dealing with budget deficits, frequently label the government as irresponsible and the corresponding 'excessive' spending levels as profligate and wasteful (Cardoso and Helwege, 1991; Altman and Haass, 2010). If this is the case, the same seems to be applicable to monetary policy in Brazil, mainly regarding, but not exclusively, the ITR. Using the same criterion, the $\mathrm{BCB}$ should be labeled irresponsible for maintaining very high nominal and real interest rates, with no trivial burdens on the nominal budget deficits (Weisbrot et al., 2017) that are financed with bonds indexed to interest rates indexed to inflationary expectations of bondholders. In this case, the fiscal "irresponsibility" is more likely a side effect of an 'irresponsible' monetary policy. This policy is wasteful regarding GDP growth and decent employment policies when compared to other countries, although it is still profligate regarding the rentiers' interests well served by this very monetary framework of unnecessary transfers from taxpayers.

\section{Conclusion}

The article suggests that the ITR in Brazil does not seem to be an effective monetary policy if we follow Keynes' views. The ITR in Brazil has not managed to achieve low and stable inflation rates, despite having one of the highest average nominal and real interest rates. Why? Because inflation rate in Brazil is not related to an excess of credit-funded demand (credit channel), but cost-push inflation and other different determinants, such as, external transmissions, distributive conflicts, and supply shocks.

Given that, a demand management policy of keeping one of the highest real interest rates in the world is ineffective and simply represents an income transfers policy via a misguided debt management policy. That is, we argue that the single most important instrument for keeping excessive real interest rates in Brazil is the expectations trap that frame the monetary policy, in which the $\mathrm{BCB}$ overemphasizes the inflationary expectations of rentiers for defining interest rates, given them a power over monetary policy not likely to be seen in other countries. In other words, it seems that in Brazil there is a reversed liquidity trap, with interest rates trapped at high levels because rentiers are 'trapped' in liquid bonds whose payoff is linked to high interest rates set according to their own expectations. So, paraphrasing Kalecki, they earn what they expect to earn. 
Although the goal of this article is not to provide policy prescriptions, and keeping in mind that more meaningful research is always needed when practical matters are involved, if Brazil aims at achieving price and financial stability, low unemployment, and higher and sustainable growth rates by means of productive investment, that is, all the features highlighted by Keynes and the Post-Keynesian literature over the year as being the desirable goals of monetary policy, the ITR does not seem to have been the answer. An alternative along the lines of a rule of parking the interest rates (Rochon and Setterfield, 2008) is therefore necessary, for the sake of reducing inflation, boosting real GDP and employment growth, and minimizing income and wealth concentration.

\section{References}

Altman, R. C., \& Haass, R. N. (2010). American Profligacy and American Power. Foreign Affairs, 89(6), 25-34.

Arestis, P. (2015). Coordination of fiscal with monetary and financial stability policies can better cure unemployment. Review of Keynesian Economics, 3(2), 233-247. https://doi.org/10.4337/roke.2015.02.07

Arestis, P., \& Sawyer, M. (2013). Economic and Monetary Union Macroeconomic Policies. Basingstoke: Palgrave Macmillan. https://doi.org/10.1057/9781137317896

Arestis, P., Ferrari Filho, F., \& Terra, F. (2016). Post Keynesian macroeconomic policy regime. In F. Filho Ferrari \& F. Terra (Orgs.), Keynes: Ensaios sobre os 80 anos da Teoria Geral (pp. 151-176). Porto Alegre: Tomo Editorial.

Arestis, P., Ferrari-Filho, F., \& de Paula, L. F. (2011). Inflation targeting in Brazil. International Review of Applied Economics, 25(2), 127-148. https://doi.org/10.1080/02692171.2010.483465

Arida, P., Bacha, E., \& Resende, A. (2005). Credit, interest and jurisdictional uncertainty: Conjectures on the Case of Brazil. In F. Giavazzi, I. Goldfajn, \& S. Herrera (Eds.), Inflation Targeting, Debt, and the Brazilian Experience: 1999 to 2003 (pp. 265-293). Cambridge: MIT Press.

Barbosa-Filho, N. (2008). Inflation targeting in Brazil: 1999-2006. International Review of Applied Economics, 22(2), 187-200. 
Barbosa, F. de H. (2006). The contagion effect of public debt on monetary policy: the Brazilian experience. Revista de Economia Politica, 26(2), 231-238. https://doi.org/10.1590/s0101-31572006000200004

BCB - Banco Central Do Brasil (2018b). Series Temporais. Available at: http://www.bcb.gov.br. Accessed on August 10, 2018.

BCB - Banco Central Do Brasil. (2018a). Focus - Relatório de Mercado. Brasília: BCB. Available at http://www.bcb.gov.br. Accessed on August 10, 2018.

Bresser-Pereira, L. C., \& Silva, C. G. (2008). Inflation Targeting in Brazil: A Keynesian Approach. In L. Wray \& M. Forstater (Eds.), Keynes and Macroeconomics After 70 Years (pp. 176-195). Cheltenham: Edward Elgar Publishing. https://doi.org/10.4337/9781848446205.00020

Bruno, M., Rubens, M., Araújo, E., Diawara, H., \& Reis, A. C. (2011). Finance-Led Growth Regime no Brasil: estatuto teórico, evidências empíricas e consequências macroeconômicas. Revista de Economia Política, 31(5), 730-750. https://doi.org/10.1590/s0101-31572011000500003

Cardoso, E., \& Helwege, A. (1991). Populism, profligacy, and redistribution. In R. Dornbusch \& S. Edwards (Eds.), The Macroeconomics of Populism in Latin America (pp. 45-74). Chicago: University of Chicago Press.

Davidson, P. (1994). Post Keynesian Macroeconomic Theory. Aldershot: Edward Elgar.

Dutt, A. K. (1990). Interest Rate Policy in LDCs: A Post Keynesian View. Journal of Post Keynesian Economics, 13(2), 210-232. https://doi.org/10.1080/01603477.1990.11489842

Erber, F. S. (2008). Development projects and growth under finance domination. Revue Tiers Monde, 195(3), 597. https://doi.org/10.3917/rtm.195.0597

Grabel, I. (2003). Ideology, power and the rise of independent monetary institutions in emerging economies. In J. Kirshner (Ed.), Monetary Orders: Ambiguous economics, ubiquitous politics (pp. 25-34). Ithaca: Cornell University Press.

Hansen, A. (1953). A Guide to Keynes. New York: McGraw Hill.

Hicks, J. R. (1937). Mr. Keynes and the "Classics"; A Suggested Interpretation. Econometrica, 5(2), 147-159. https://doi.org/10.2307/1907242 
Holland, M. (2006). Por que as taxas de juros reais de curto prazo são tão elevadas no Brasil? Revista Economia \& Tecnologia, 2(1), 27-42. https://doi.org/10.5380/ret.v2i1.28937

Ipeadata. (2018). Series Históricas. Brasilia: IPEA. Available at: http://www.ipeadata.gov.br. Accessed on August 10, 2018.

Keynes, J. M. (1971). A Treatise on Money: The applied theory of money. In Collected Writings of John Maynard Keynes (v. 6). London: Macmillan.

Keynes, J. M. (1972). Essays in Persuasion. In Collected Writings of John Maynard Keynes (v. 9). London: Macmillan.

Keynes, J. M. (1982). Activities 1931-1939: World crises and policies in Britain and America. In Collected Writings of John Maynard Keynes (v. 21). London: Macmillan.

Keynes, J. M. (2007). The General Theory of Employment, Interest and Money. London: Palgrave Macmillan.

Krugman, P. R., Dominquez, K. M., \& Rogoff, K. (1998). It's Baaack: Japan's Slump and the Return of the Liquidity Trap. Brookings Papers on Economic Activity, 1998(2), 137-205. https://doi.org/10.2307/2534694

Mendonca, E. L. (2018). Analise da persistencia inflacionaria no Brasil 1999-2016. Mphil Dissertation, UFRGS, Porto Alegre.

Minsky, H. (2008). John Maynard Keynes. New York: McGraw-Hill.

Modenesi, A. de M., \& de Araujo, E. C. (2013). Price stability under inflation targeting in Brazil: empirical analysis of the mechanism of transmission of the monetary policy based on a VAR model, 2000-2008. Investigacion Economica, 72(283), 99-133.

Modenesi, A., Modenesi, R. L., Oreiro, J. L., \& Martins, N. M. (2013). Convention, interest rates and monetary policy: a post-Keynesian-French-conventionsschool approach. European Journal of Economics and Economic Policies: Intervention, 10(1), 76-92. https://doi.org/10.4337/ejeep.2013.01.07

Oreiro, J. L., Paula, L. F. de, Silva, G. J. C. da, \& Amaral, R. O. do. (2012). Por que as taxas de juros são tão elevadas no Brasile: uma avaliação empírica. Revista de Economia Política, 32(4), 557-579. https://doi.org/10.1590/S0101-31572012000400002

Paula, L., \& Bruno, M. (2017). Financeirizacao, coalizão de interesses e taxa de juros no Brasil. Revista Princípios, 15(1), 66-71. 
Rochon, L.-P., \& Setterfield, M. (2008). The Political Economy of Interest-Rate Setting, Inflation, and Income Distribution. International Journal of Political Economy, 37(2), 5-25. https://doi.org/10.2753/ijp08911916370201

Samuels, D. (2001). Money, Elections, and Democracy in Brazil. Latin American Politics and Society, 43(02), 27-48. https://doi.org/10.1111/j.15482456.2001.tb00398.x

Seabra, L., \& Dequech, D. (2013). Convenções financeiras e a taxa básica de juros no Brasil: uma primeira aproximação. Revista de Economia Política, 33(4), 599-618. https://doi.org/10.1590/S0101-31572013000400003

Smithin, J. (1996). Macroeconomic Policy and the Future of Capitalism: The revenge of the rentiers and the Threat to Prosperity. Cheltenham: Edward Elgar.

Summa, R., \& Serrano, F. (2018). Distribution and Conflict Inflation in Brazil under Inflation Targeting, 1999-2014. Review of Radical Political Economics, 50(2), 349-369. https://doi.org/10.1177/0486613417691787

Vernengo, M. (2008). The Political Economy of Monetary Institutions in Brazil: The Limits of the Inflation-targeting Strategy, 1999-2005. Review of Political Economy, 20(1), 95-110. https://doi.org/10.1080/09538250701661863

Weisbrot, M., Johnston, J., Carrillo, J. V., \& Mello, V. (2017). Brazil's Enormous Interest Rate Tax: Can Brazilians Afford It? CEPR Reports (Vol. 2017). Available at: http://www.cepr.net/images/stories/reports/brazil-interestrates-2017-04.pdf. Accessed on October 10, 2018.

Zabot, U. C., Caetano, S. M., \& Caldeira, J. F. (2013). Antecipação e surpresa monetária e seus efeitos nas taxas de juros de mercado. Economia Aplicada, 172), 227-249. https://doi.org/10.1590/S141380502013000200003 